\title{
Kesalahan Pemahaman Konsep Peserta Didik dalam Menyelesaikan Soal- Soal Integral Lipat Dua pada Koordinat Polar
}

\author{
Rahma Siska Utari ${ }^{1 *}$, Liana Septy ${ }^{2}$, Lusinda Hutauruk ${ }^{3}$ \\ ${ }^{1}$ Pendidikan Matematika, Universitas Sjakhyakirti, Palembang \\ ${ }^{2}$ Pendidikan Matematika, UIN Raden Fatah, Palembang \\ ${ }^{3}$ Pendidikan Matematika, STIA Balaputra Dewa, Palembang \\ *ama.utari@gmail.com
}

\begin{abstract}
Abstrak
Penelitian ini adalah penelitian deskriptif kualitatif untuk menganalisis kesalahan pemahaman konsep peserta didik dalam menyelesaikan soal-soal integral lipat dua pada koordinat polar. Tiga puluh peserta didik yang mengambil mata kuliah kalkulus peubah banyak menjadi subjek dalam penelitian ini. Data dikumpulkan dengan menggunakan tes dan dokumentasi. Hasil jawaban tes peserta didik serta dokumentasi hasil pengerjaan peserta didik, dikoreksi, dianalisis berdasarkan indikator pemahaman konsep dan didisplay data. Analisis kesalahan jawaban peserta didik berdasarkan indikator pemahaman konsep yakni (1) menyatakan ulang konsep integral. (2) merepresentasikan konsep ke bentuk lain, (3) memilih dan menggunakan prosedur serta (4) menggunakan konsep dan algoritma pemecahan masalah. Dalam menyatakan ulang konsep integral peserta didik langsung menggunakan batas atas dan batas bawah integrasi tanpa menuliskan terlebih dahulu hasil pengintegralan. Kesalahan merepresentasikan fungsi ke grafik adalah, fungsi langsung disketsakan tanpa membuat table, memplot titik dan membuat kurva. Kesalahan dalam memilih dan menggunakan prosedur dan penggunaan algoritma pemecahan masalah dikarenakan kurangnya pengetahuan awal peserta didik mengenai materi prasyarat yakni, integral trigonometri dan fungsi trigonometri.
\end{abstract}

Kata Kunci: Integral Lipat Dua, Koordinat Polar

\begin{abstract}
This research was a qualitative descriptive study to analyze the misunderstanding of students' concepts in solving two fold integral problems on polar coordinates. The 30 students who took the multivariable calculus course became the subjects in this study. Data were collected using tests and documentation. The results of the student's test answers and the documentation of students answers were corrected, analyzed based on indicators of conceptual understanding and data displayed. Analysis of students' answer errors based on indicators of concept understanding, namely (1) restating the integral concept. (2) representing the concept in other forms, (3) selecting and using procedures and (4) using problem solving concepts and algorithms. In restating the integral concept, students directly use the upper and lower limits of integration without writing down the integration results first. The mistake of representing the function to the graph is that the function is immediately sketched without creating a table, plotting points and creating curves. Errors in selecting and using procedures and using problem solving algorithms are due to students' lack of prior knowledge of prerequisite materials, namely trigonometric integrals and trigonometric functions.
\end{abstract}

Keywords: Polar Coordinates, Two Fold Integral

Received: November 19, 2020 / Accepted: January 18, 2021/ Published Online: January 28, 2021 


\section{PENDAHULUAN}

Integral lipat dua pada koordinat polar dipelajari pada mata kuliah kalkulus peubah banyak atau kalkulus multivariabel. Kumpulan titik-titik yang membentuk kurva tertentu seperti lingkaran, kardioida dan mawar lebih mudah diuraikan dan dihitung integral lipat duanya menggunakan koordinat polar (Varberg, Purcell, \& Rigdon, 2011; Suarsana, 2014; Imaniyah, 2019). Selain itu, koordinat polar juga digunakan dalam pemberian jarak berarah dari sepasang sumbu tegak lurus yang digunakan untuk merinci suatu titik (Varberg, Purcell, \& Rigdon, 2011). Dalam koordinat polar kedudukan suatu titik dapat dinyatakan dalam tak hingga banyaknya koordinat (Suarsana, 2014). Materi integral lipat dua pada koordinat polar terintegrasi pada materi koordinat polar dan integral lipat dua. Sehngga pematangan konsep dasar kordinat polar dan konsep dasar integral serta integral lipat dua penting untuk dimiliki oleh peserta didik. Wujud dari pematangan konsep tersebut dapat ditunjukkan dengan gestur menunjuk, representasi dan menulis (Sulistyorini, 2019).

Muchlis (2017) menyatakan bahwa untuk mempelajari integral lipat dua sebaiknya memvisualisasikan gambar beserta daerah penyelesaian integral, selain itu peserta didik hendaknya memahami konsep dengan mengungkapkan kembali makna konsep dengan bahasa sendiri. Mengungkapkan kembali makna konsep dengan bahasa sendiri dapat dilihat dari jawaban peserta didik dalam penyelesaian soal-soal integral. Utari \& Utami (2020) serta Farhan \& Zulkarnain (2019) menyatakan bahwa beberapa hal yang dapat dilakukan untuk dapat menyelesaikan soal-soal integral seperti membaca dan memahami konsep dasar integral, melakukan latihan soal bervariasi dan jika mengalami kendala berkonsultasi dengan dosen pengampu. Semakin sering dan bervariasinya soal-soal integral yang diberikan, semakin banyak juga indikator pemahaman konsep yang dapat dimunculkan (Hw, 2017).

Memahami konsep integral lipat dua penting bagi peserta didik. Selain mendukung peserta didik dalam memahami mata kuliah kalkulus peubah banyak, memahami materi koordinat polar juga berfungsi untuk mendukung peserta didik pada mata kuliah geometri analitik bidang datar dan ruang, tetapi pada kenyataannya peserta didik masih mengalami kesulitan dalam mempelajari integral lipat dua pada koordinat polar (Apriandi \& Krisdiana, 2016; Nurmalitasari, 2017). Apriandi \& Krisdiana (2016) menyatakan bahwa beberapa kesulitan yang dihadapi oleh peserta didik dalam materi integral lipat dua koordinat polar, yakni: (a) peserta didik mengalami kesulitan dalam menggambar fungsi pada koordinat polar dan menentukan daerah integrasi, (b) peserta didik mengalami kesulitan dalam mengubah variabel ke koordinat polar, (c) peserta didik mengalami kesulitan dalam menentukan batas integrasi, (d) peserta didik mengalami kesulitan dalam menuliskan bentuk integrasi dan (e) 
e-ISSN : 2656-7245 Kesalahan Pemahaman Konsep Peserta Didik dalam Menyelesaikan Soal-Soal Integral Lipat Dua pada Koordinat Polar

peserta didik kesulitan dalam menghitung integrasi. Faktor lain yang menyebabkan adanya kesulitan belajar pada integral lipat dua koordinat polar adalah kesehatan, kelelahan, interaksi dosen dengan peserta didik, alat penunjang pembelajaran, media pembelajaran, materi kalkulus peubah banyak dan motivasi (Nurmalitasari, 2017).

Kesulitan yang dihadapi oleh peserta didik menyebabkan sering terjadinya kesalahan dalam menyelesaikan soal-soal. Kesalahan tersebut erat kaitannya dengan pemahaman konsep integral lipat dua yang dimiliki oleh peserta didik. Ketika kemampuan pemahaman konsep peserta didik baik maka kesalahan yang dilakukan tidak terlalu fatal bahkan tidak melakukan kesalahan dalam menyelesaikan soal (Damayanti, Mayangsari, \& Mahardhika, 2017). Konsep merupakan hal mendasar yang harus dimiliki oleh peserta didik dalam belajar. Ketika konsep yang digunakan keliru maka dalam memilih prosedur, menggunakan prosedur dan menyelesaikan soal juga akan mengalami kesulitan (Kesumawati, 2008; Oktavianti, Ardiansah, \& Putra, 2019). Kesalahan konsep yang sering dilakukan oleh peserta didik dalam mempelajari integral yakni, kesalahan dalam menentukan nilai batas, menghitung integral yang disebabkan oleh ketidak telitian dalam menyelesaikan soal, tidak memahami konsep pengintegralan dan hanya menghapal konsep (Wahyuni, Kurniawan, Waluya, \& Cahyini, 2019).

Berdasarkan hal tersebut hendaknya pemahaman konsep peserta didik pada materi integral lipat dua koordinat polar harus dimatangkan terlebih dahulu. Menganalisis kesalahan peserta didik dalam menyelesaikan soal integral lipat dua pada koordinat polar dapat membantu untuk evaluasi pembelajaran berikutnya (Raupu, Thalhah \& Mattoliang, 2020). Oleh sebab itu, penelitian ini bertujuan untuk menganalisis kesahalan pemahaman konsep peserta didik dalam menyelesaikan soal-soal integral lipat dua koordinat polar.

\section{METODE}

Penelitian ini adalah penelitian deskriptif kualitatif. Subjek dalam penelitian ini adalah 30 peserta didik semester empat tahun ajaran 2019/2020 yang mengambil mata kuliah kalkulus peubah banyak. Penelitian ini dilaksanakan di Fakultas Ilmu Tarbiyah dan Keguruan UIN Raden Fatah Palembang Program Studi Pendidikan Matematika. Adapun indikator pemahaman konsep yang digunakan dalam penelitian ini dan nomor butir soal dapat dilihat pada Tabel 1 berikut. 
Tabel 1. Indikator Pemahaman Konsep dan Nomor Butir Soal

\begin{tabular}{llc}
\hline No & \multicolumn{1}{c}{ Indikator Pemahaman Konsep } & Nomor Butir Soal \\
\hline 1 & Menyatakan ulang sebuah konsep & 1 \\
\hline 2 & Merepresentasikan konsep ke bentuk lain & 2 \\
\hline 3 & Memilih dan menggunakan prosedur yang sesuai & 3 \\
\hline 4 & $\begin{array}{l}\text { Menggunakan konsep dan memilih algortitma penyelesaian } \\
\text { masalah }\end{array}$ & 4
\end{tabular}

(Modifikasi Depdiknas, 2006)

Pada penelitian ini data dikumpulkan dengan menggunakan teknik tes dan dokumentasi. Tes digunakan untuk mengetahui kesalahan pemahaman konsep peserta didik dalam menjawab soal-soal integral lipat dua pada koordinat polar. Soal tes yang diberikan adalah soal yang sesuai dengan indikator pemahaman konsep yang digunakan yang bersesuaian dengan Tabel 1. Soal tes yang digunakan telah divalidasi oleh expert review dibidang kalkulus dan telah dinyatakan valid dan praktis.

Penelitian ini dilaksanakan semasa pandemi Covid-19 dan diberlakukannya Pembelajaran Jarak Jauh (PJJ), sehingga penelitian dilaksanakan secara daring dengan menggunakan applikasi whatsapp group dan google classroom. Whatsapp group dan google classroom digunakan dalam pembelajaran. Sedangkan tes dilakukan dengan menggunakan google classroom. Hasil jawaban peserta didik yang telah dikumpulkan pada google classroom kemudian dikoreksi, dianalisis dan didisplay data. Dokumentasi digunakan sebagai data pendukung untuk menjelaskan jawaban peserta didik. Setelah data dianalisis, kemudian diambil kesimpulan.

\section{HASIL PENELITIAN}

Sebelum diadakannya tes mengenai integral lipat dua pada koordinat polar, dilakukan terlebih dahulu pembelajaran dan diskusi kelas dengan menggunakan whatsapp group, seperti dokumentasi pada Gambar 1 berikut ini.
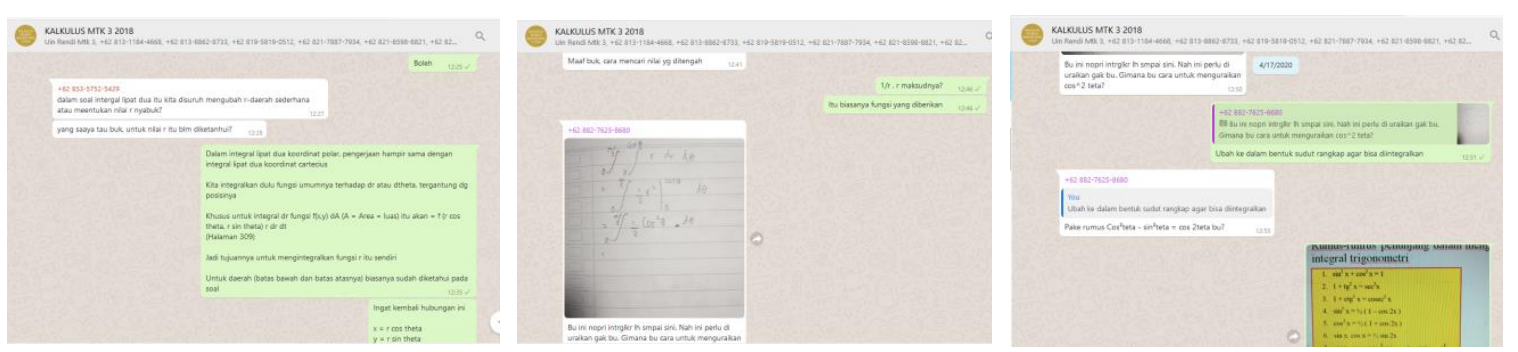

Gambar 1. Diskusi kelas terkait materi integral lipat dua koordinat polar 1

Materi prasyarat untuk mempelajari integral lipat dua pada koordinat polar adalah turunan, integral, fungsi trigonometri dan koordinat polar yang sebelumnya telah dipelajari. 
e-ISSN : 2656-7245 Kesalahan Pemahaman Konsep Peserta Didik dalam Menyelesaikan Soal-Soal Integral Lipat Dua pada Koordinat Polar

Gambar 1 di atas menujukkan interaksi antara peserta didik dan dosen pengampu terkait konsep integral lipat dua pada koordinat polar. Peserta didik menanyakan bagaimana mencari batas atas dan batas bawah pada integral lipat dua koordinat polar, dan bagaimana cara menguraikan $\cos ^{2} \vartheta$. Cara mengintegralkan dari $\cos ^{2} \vartheta$ adalah dengan mengubah bentuknya terlebih dahulu ke dalam bentuk sudut rangkap yakni $\cos ^{2} \vartheta=\frac{1}{2}(1+\cos 2 \theta)$. Ketika fungsi sudah diubah ke bentuk sudut rangkap, maka fungsi tersebut sudah dapat diintegralkan.

Setelah dilakukan diskusi kelas dan latihan kelas maka dilakukanlah tes. Hasil tes peserta didik pada materi integral lipat dua koordinat polar berdasarkan keterangan pada google classroom menunjukkan nilai rata-rata kelas sebesar 77,29 seperti tertera pada Gambar $\underline{2}$ berikut.

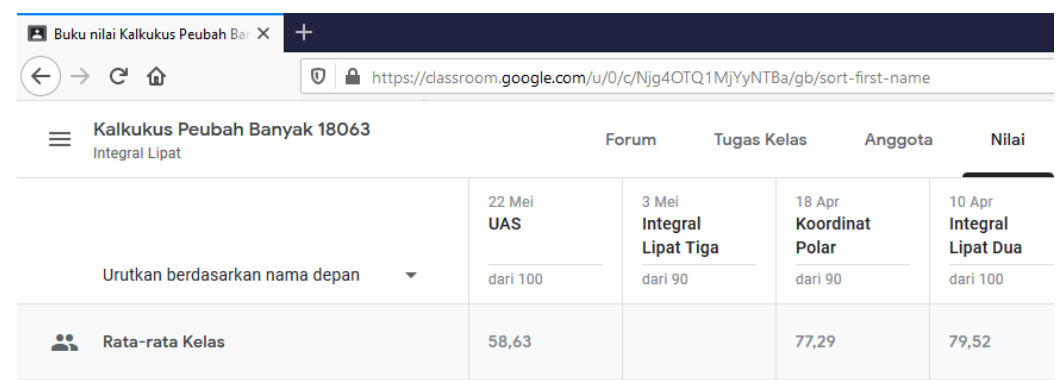

Gambar 2. Rata-rata kelas materi integral lipat dua koordinat polar

Gambar 2 di atas menunjukkan bahwa Tes integral lipat dua pada koordinat polar dilaksanakan pada tanggal 18 April 2020 dengan jumlah peserta didik yang mengikuti perkuliahan sebanyak 30 peserta didik. Dengan menggunakan aplikasi google classroom yang menyediakan menu classwork serta submenu assignment untuk membuat tes membantu peneliti dalam menghimpun jawaban tes peserta didik, menetapkan poin dan rubrik penskoran, mengatur waktu pengumpulan tes serta menilai (mengoreksi) jawaban tes peserta didik secara online. Hasil yang terdapat pada google classroom (Gambar 2) memiliki rata-rata kelas 77,29. Selanjutnya akan dijabarkan kesalahan pemahaman konsep peserta didik untuk setiap indikator.

\section{Kesalahan dalam Menyatakan Ulang Konsep Integral}

Menyatakan ulang konsep integral merupakan hal yang krusial dan penting dilakukan sebelum melakukan suatu pengintegralan terhadap suatu fungsi. Sering kali terjadi kesalahan dalam menyatakan ulang konsep integral, seperti Gambar 3 berikut ini. 


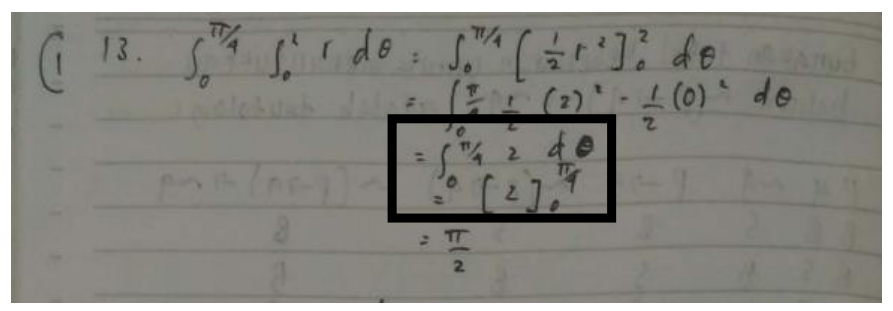

Gambar 3. Jawaban subjek 1 dalam menuliskan ulang konsep integral

Varberg, Purcel \& Rigdon (2011) menyatakan bahwa berdasarkan teerema D Kelinearan Integral Tentu yang berbunyi misalkan $\mathrm{f}$ dan $\mathrm{g}$ terintegrasi pada $[\mathrm{a}, \mathrm{b}]$ dan $\mathrm{k}$ adalah konstanta. Maka kf adalah integrasi dari $\int_{\mathbf{a}}^{\mathbf{b}} \mathbf{k} \mathbf{f}(\mathbf{x}) \mathbf{d x}=\mathbf{k} \int_{\mathbf{a}}^{\mathbf{b}} \mathbf{f}(\mathbf{x}) \mathbf{d x}$. Pada Gambar 3 di atas terlihat bahwa Subjek 1 salah/ keliru dalam menyatakan kembali konsep integral. Subjek 1 menuliskan $\int_{0}^{\frac{\pi}{4}} \mathbf{2} \mathbf{d} \boldsymbol{\theta}=\left.2\right|_{0} ^{\frac{\pi}{4}}$ padahal berdasarkan teeroma D seharusnya konsep yang ditulis ulang kembali adalah $\int_{0}^{\frac{\pi}{4}} \mathbf{2} \mathbf{d} \boldsymbol{\theta}=\mathbf{2} \int_{\mathbf{0}}^{\frac{\pi}{4}} \mathbf{d} \boldsymbol{\vartheta}=\left.\mathbf{2} \boldsymbol{\theta}\right|_{\mathbf{0}} ^{\frac{\pi}{4}}$. Kesalahan yang dilakukan oleh Subjek 1 ini termasuk dalam kategori kesalahan dalam menyatakan ulang konsep integral.

\section{Kesalahan dalam Merepresentasikan Fungsi Koordinat Polar ke dalam Grafik}

Untuk merepresentasikan fungsi ke bentuk grafik/ mensketsakan fungsi ke bentuk grafik dalam integral lipat dua koordinat polar. ada beberapa hal yang harus dilakukan terlebih dahulu yakni membuat table yang untuk menentukan titik-titik yang memenuhi persamaan, memplot titik-titik pada koordinat polar, membentuk kurva mulus dari plot titiktitik tersebut (Varberg, Purcell \& Rigdon, 2011). Ketika langkah-langkah tersebut sudah dilakukan maka akan terbentuklah grafik yang ada di koordinat polar, tetapi lain halnya ketika langkah tersebut tidak dilakukan maka akan terdapat kesalahan seperti jawaban dari Subjek 2 pada Gambar 4 berikut ini.

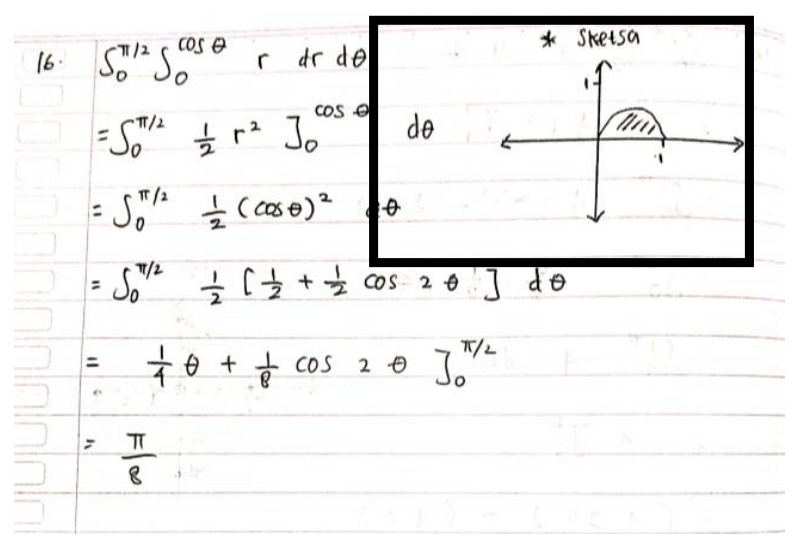

Gambar 4. Jawaban subjek 2 dalam menggambar grafik koordinat polar 
Gambar 4 di atas menunjukkan bahwa Subjek 2 melakukan sketsa secara langsung tanpa membuat table terlebih dahulu untuk menentukan titik-titik yang memenuhi persamaan, kemudian tidak ada plot titik-titik pada koordinat polar dan kurva yang dibentuk juga tidak berhadasarkan plot titik-titik yang sudah dibuat sebelumnya, Sehingga dapat dikatakan bahwa sketsa yang dibuat tidak berdasarkan langkah-langkah yang telah dikemukan oleh Varberg, Purcell \& Rigdon (2011).

\section{Kesalahan dalam Memilih dan Menggunakan Prosedur Tertentu}

Ketika memilih dan menggunakan suatu prosedur yang perlu disadari untuk menyelesaikan permasalah tersebut apakah prosedur tersebut sudah sesuai untuk dipilih dan digunakan ataukah tidak sesuai. Dalam menyelesaikan soal-soal yang mengandung fungsi polinom pada integral fungsi trigonometri. Hal yang dilakukan adalah mengubah bentuk polinom pada fungsi trigonometri tersebut kesudut rangkap ataupun menggunakan teorema bentuk-bentuk integral trigonometri (Varberg, Purcell, \& Rigdon, 2011). Gambar 5 berikut ini adalah jawaban Subjek 3 dalam memilih dan menggunakan prosedur untuk menyelesaikan soal.

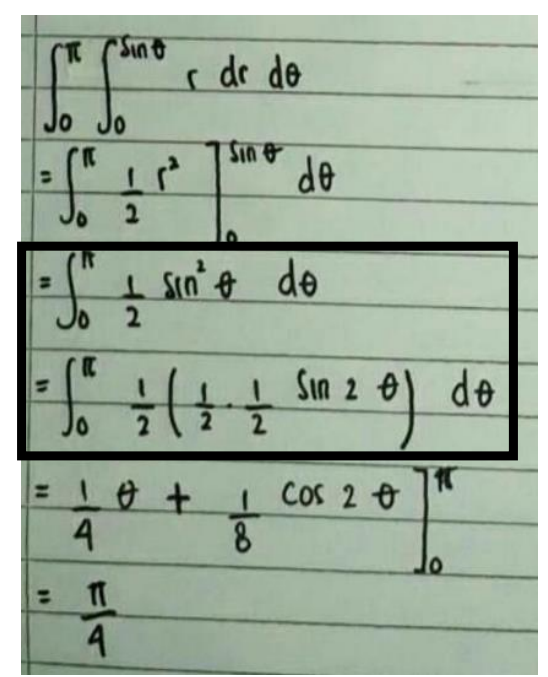

Gambar 5. Jawaban subjek 3 dalam memilih dan menggunakan prosedur

Gambar 5 di atas menujukkan kesalahan yang dilakukan peserta didik dalam menyelesaikan soal integral fungsi trigonometri. Subjek 3 menuliskan $\int_{0}^{\pi} \frac{1}{2} \sin ^{2} \theta \mathbf{d} \theta=$ $\int_{0}^{\pi} \frac{1}{2}\left(\frac{1}{2}-\frac{1}{2} \sin 2 \vartheta\right) d \theta$ padahal bentuk sudut rangkapnya adalah $\sin ^{2} \theta=\frac{1}{2}-\frac{1}{2} \cos 2 \theta$. Berdasarkan Gambar 5, Prosedur yang dipilih oleh Subjek 3 salah dan penggunaannya juga salah, sehingga prosedur yang seharusnya dipilih adalah $\int_{0}^{\pi} \frac{1}{2} \sin ^{2} \theta d \theta=\int_{0}^{\pi} \frac{1}{2}\left(\frac{1}{2}-\frac{1}{2} \cos 2 \theta\right) d \theta=\frac{1}{4} \int_{0}^{\pi} d \theta-\frac{1}{4} \int_{0}^{\pi} \cos 2 \theta d \theta=\frac{\theta}{4}-\left.\frac{1}{8} \sin 2 \theta\right|_{0} ^{\pi}$. 


\section{Kesalahan dalam Menggunakan Konsep dan Memilih Algortitma Pemecahan Masalah}

Kesalahan dalam penggunaan konsep dan algoritma pemecahan masalah sering kali terjadi dalam fungsi trigonometri yang memang digunakan dalam koordinat polar. Seperti kesalahan pada Gambar 6 berikut ini.

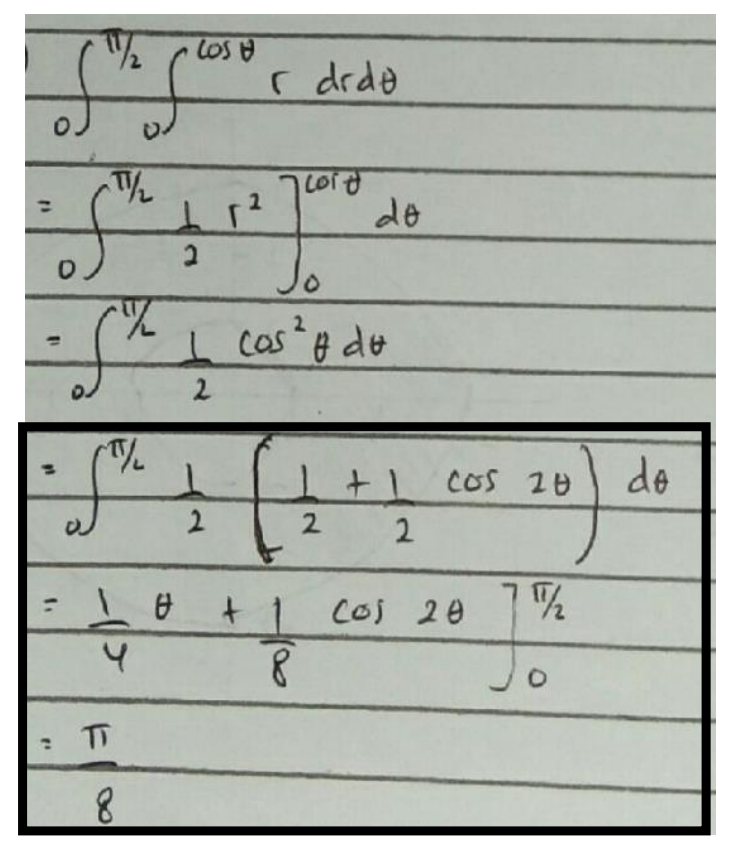

Gambar 6. Jawaban Subjek 4 dalam menggunakan konsep integral trigonometri

$\underline{\text { Gambar } 6}$ di atas menujukkan bahwa kesalahan penggunaan konsep integral trigonometri yang seharusnya $\int_{0}^{\frac{\pi}{2}} \cos 2 \vartheta d \theta=\left.\frac{1}{2} \sin 2 \theta\right|_{0} ^{\frac{\pi}{2}}$ bukan $\int_{0}^{\frac{\pi}{2}} \cos 2 \vartheta d \theta=$ $\left.\frac{1}{2} \cos 2 \theta\right|_{0} ^{\frac{\pi}{2}}$. Secara keseluruhan seharusnya penggunaan konsep dan algoritma pemecahan masalah yang digunakan adalah $\int_{0}^{\frac{\pi}{2}} \frac{1}{2}\left(\frac{1}{2}+\frac{1}{2} \cos 2 \theta\right) \mathrm{d} \theta=\frac{1}{4} \int_{0}^{\frac{\pi}{2}} d \theta+\frac{1}{4} \int_{0}^{\frac{\pi}{2}} \cos 2 \vartheta d \theta=$ $\left.\frac{\boldsymbol{\theta}}{\mathbf{4}}\right|_{\mathbf{0}} ^{\frac{\pi}{2}}+\left.\frac{\sin 2 \boldsymbol{\theta}}{\mathbf{8}}\right|_{\mathbf{0}} ^{\frac{\pi}{2}}$. Sehingga dapat dikatakan bahwa Subjek 4 melakukan kesalahan dalam menggunakan konsep dan memilih algortitma pemecahan masalah.

\section{PEMBAHASAN}

Pemahaman konsep merupakan hal mendasar ketika mempelajari suatu materi pada matematika. Sama halnya ketika mempelajari integral lipat dua pada koordinat polar, peserta didik diharuskan untuk memahami konsep koordinat polar, integral, turunan, fungsi trigonometri dan integral lipat dua (Varberg, Purcell, \& Rigdon, 2011; Hw, 2017. Kesalahan dalam memahami konsep integral lipat dua pada koordinat polar yang dilakukan oleh peserta 
e-ISSN : 2656-7245 Kesalahan Pemahaman Konsep Peserta Didik dalam Menyelesaikan Soal-Soal Integral Lipat Dua pada Koordinat Polar

didik berdasarkan indikator pemahaman konsep yang digunakan pada penelitian ini adalah peserta didik melakukan kesalahan dalam menyatakan ulang konsep integral. Kesalahan yang dilakukan oleh peserta didik seperti tidak menuliskan hasil integral setelah proses pengintegralan tetapi langsung memasukan batas atas dan batas bawah integral. Kesalahan ini sering juga dilakukan oleh peserta didik dalam mempelajari integral, seperti pada penelitian Apriandi \& Krisdiana (2016) yang menunjukkan bahwa peserta didik mengalami kesulitan dalam menuliskan bentuk integrasi, sehingga terjadi kesalahan dalam menyatakan ulang konsep integral.

Kesalahan pemahaman konsep lainnya yang berdasarkan jawaban tes peserta didik adalah kesalahan dalam merepresentasikan fungsi ke grafik/ kurva pada koordinat polar. Kesalahan terjadi karena peserta didik tidak mengikuti langkah-langkah penggambaran grafik, peserta didik langsung saja mengsketsakan grafik tanpa melakukan langkah awal terlebih dahulu. Seperti yang dikemukan oleh Varberg, Purcell, \& Rigdon (2011) yang menyatakan bahwa untuk menggambar grafik koordinat polar maka hal yang perlu dilakukan adalah membuat tabel untuk mengetahui titi-titik yang memenuhi sesuai dengan fungsi, lalu memplot titik-titik tersebut pada koordinat polar dan menghubungkan titik-titik membentuk kurva mulus. Kesulitan yang berujung pada kesalahan dalam merepresentasikan bentuk integral ini juga dikemukan oleh Apriandi \& Krisdiana (2016) yang menyatakan bahwa kesulitan yang dialami oleh peserta didik salah satunya dalam menggambar fungsi pada koordinat polar dan menentukan daerah integrasi. Selain itu hal ini bersesuaian dengan pendapat Ningtyas, Fuad, \& Lukito (2019) yang menyatakan bahwa dalam merepresentasikan ide-ide matematika dalam menyelesaikan soal-soal kalkulus, peserta didik mampu menampilkan ide-ide secara multirepresentatif namun tidak lengkap, tidak runut dan tidak tepat secara numerik.

Dalam memilih dan menggunakan prosedur serta mengaplikasikan algoritma pemecahan masalah tidak dapat dingkuri bahwa pengetahuan awal peserta didik mengenai materi prasyarat yakni, turunan, integral, bentuk-bentuk trigonometri dan koordinat polar harus dipahami terlebih dahulu. Sehingga proses pengerjaannya akan lancar sampai ke hasil. Kesalahan dalam memilih prosedur dan menggunakan algortima pemecahan masalah disebabkan karena kurangnya pengetahuan awal tentang integral fungsi trigonometri dan juga kurangnya waktu diskusi kelas dan latihan soal yang terbatas, untuk sampai pada tahapan memilihi dan menggunakan prosedur sampai aplikasi algoritma dalam pemecahan masalah peserta didik diharapkan untuk melakukan latihan soal bervariasi. Hal ini didukung oleh pendapat dari Utari \& Utami (2020) menyatakan bahwa beberapa hal yang dapat dilakukan untuk dapat menyelesaikan soal-soal integral seperti membaca dan memahami konsep dasar 
integral, melakukan latihan soal bervariasi dan jika mengalami kendala berkonsultasi dengan dosen pengampu.

\section{SIMPULAN}

Kesalahan pemahaman konsep peserta didik pada materi integral lipat dua pada koordinat polar adalah peserta didik melakukan kesalahan dalam menyatakan ulang konsep integral, peserta didik langsung memasukan batas atas dan batas bawah integrasi tanpa menuliskan hasilnya pengintegral terlebih dahulu. Kesalahan dalam menggambar grafik fungsi juga terjadi karena peserta didik tidak melakukan langkah awal dalam menggambar grafik tetapi langsung mensketsakan grafik tanpa membuat tabel dan memplot titik-titik terlebih dahulu. Kesalahan dalam memilih prosedur dan mengaplikasikan algoritma pemecahan masalah juga terjadi karena belum matangnya konsep materi fungsi trigonometri dan integral trigonometri serta kurangnya melakukan latihan soal-soal bervariasi sehingga peserta didik belum bisa memilih prosedur yang tepat.

\section{DAFTAR PUSTAKA}

Apriandi, D., \& Krisdiana, I. (2016). Analisis Kesulitan Mahasiswa dalam Memahami Materi Integral Lipat Dua Pada Koodinat Polar Mata Kuliah Kalkulus Lanjut. Al Jabar : Jurnal Pendidikan Matematika, 7 (2), 123-134. doi : https://doi.org/10/24024/ajpm.v7i2.19.

Damayanti, N. W., Mayangsari, S. N., \& Mahardhika, L. T. (2017). Analisis Kesalahan Siswa dalam Pemahaman Konsep Operasi Hitung pada Pecahan. Jurnal Ilmiah Edutic, 4 (1), $1-7$.

Depdiknas. (2006). Standar Kompetensi dan Kompetensi Dasar Matematika SMA/MA. Jakarta: Depdiknas.

Farhan, M., \& Zulkarnain, I. (2019). Analisis Kesalahan Mahasiswa pada Mata Kuliah Kalkulus Peubah Bnyak Berdasarkan Newmann's Error Analisis. JKPM Jurnal Kajian Pendidikan Matematika, 4
https://dx.doi.org/10.30998/ikpm.v412.3843

Hw, S. (2017). Kalkulus Peubah Banyak. Surakarta: Muhammadiyah University Press.

Imaniyah, A. (2019). Pembuktian Rumus Keliling Lingkaran dengan Integral Polar. Prosiding pada Seminar Nasional Pendidikan Matematika (SENANDIKA) 2019. Malang : Universitas Islam Malang.

Kesumawati, N. (2008). Pemahaman Konsep Matematik dalam Pembelajaran Matematika. Prosiding pada Seminar Nasional Matematika dan Pendidikan Matematika 2008, 229235. Yogyakarta: Universitas Negeri Yogyakarta.

Muchlis, E. E. (2017). Analisis Kesalahan Mahasiswa pada Materi Integral Lipat di Prodi Pendidikan Matematika FKIP Universitas Bengkulu. Seminar Matematika dan Pendidikan Matematika UNY (pp. 265-272). Yogyakarta: UNY. 
e-ISSN : 2656-7245 Kesalahan Pemahaman Konsep Peserta Didik dalam Menyelesaikan Soal-Soal Integral Lipat Dua pada Koordinat Polar

Ningtyas, D. Y., Fuad, Y., \& Lukito, A. (2019). Kemampuan Representasi Mahasiswa Pendidikan Matematika dalam Menyelesaikan Soal Kalkulus. Kreano, Jurnal Matematika Kreatif Inovatif, 10 (1), 27-36. https://doi.org/10/15294/kreano.v10i1.17334

Nurmalitasari, D. (2017). Analisis Kesulitan Belajar Mahasiswa pada Mata Kuliah Kalkulus Peubah Banyak di STKIP PGRI Pasuruan. Educazione, 5 (1), 27-35.

Oktavianti, E., Ardiansah, F., \& Putra, Y, Y. (2019). Pengaruh Teori Van Hiele terhadap Pemahaman Konsep Matematika Materi Bangun Ruang Kubus pada Siswa Kelas V SD Negeri 46 Pangkalpinang. Jurnal Inomatika : Inovasi Matematika, 1 (1), 66-76. doi: https://doi.org/10.35438/inomatika.v1i1.140

Raupu, S., Thalhah, S. Z., \& Mattoliang, L. A. (2020). Learning Diffucties in Solving Calculus Tests. MaPan : Jurnal Matematika dan Pembelajaran, 8 (2). 168 -178. doi: https://doi.org/10.24252/mapan.2020v8n2a1

Suarsana, I. M. (2014). Geometri Analitik. Yogyakarta: Graha Ilmu.

Sulistyorini, Y. (2019). Gestur dalam Pembelajaran Matematika Materi Irisan Kerucut dan Koordinat Polar. SUPERMAT Jurnal Pendidikan Matematika, 3 (1), 1-9. doi : https://doi.org/10.33627/sm.v3i1.147

Utari, R. S., \& Utami, A. (2020). Kemampuan Pemahaman Konsep Mahasiswa dalam mengidentifikasi penyelesaian soal integral tak tentu dan tentu. Jurnal Pendidikan Matematika, 14 (1), 39-50. doi: https://doi.org/10.22342/jpm.14.1.6820.39-50

Varberg, D., Purcell, E. J., \& Rigdon, S. E. (2011). Kalkulus Edisi Kesembilan Jilid 1. Jakarta: Erlangga.

Wahyuni, A., Kurniawan, P., Waluya, S. B., \& Cahyini, A. N. (2019). Analisis Kesalahan Mahasiswa dalam Menyelesaikan Soal Integral. Seminar Nasional Edusaintek FMIPA UNIMUS (pp. 623-629). Semarang: FMIPA Universitas Muhammadiyah Semarang. 